\title{
The Amyloid Cascade Hypothesis: are we poised for success or failure?
}

\author{
Karran E, De Strooper B
}

Alzheimer's Research UK Research, Cambridge, Cambridgeshire, UK

+VIB Center for the Biology of Disease, VIB-Leuven, Leuven, Belgium

$\ddagger$ Center for Human Genetics, Universitaire ziekenhuizen and LIND, KU Leuven, Leuven, Belgium

§Institute of Neurology, University College London, London, UK

The first description of Alzheimer's disease (AD) was made in 1907 by Alois Alzheimer (Alzheimer 1907), although other contemporary physicians had made similar, and rather more complete, assessments of the neuropathological changes present in the AD brain (Fischer 1907). Our knowledge of AD has increased dramatically and continues to accelerate. This year is 25 years after the publication of a series of papers that, in various ways, articulated the amyloid cascade hypothesis (ACH) for AD (Hardy \& Allsop 1991, Beyreuther \& Masters 1991, Selkoe 1991, Hardy \& Higgins 1992). This review will cover some familiar territory, but we shall also place the $\mathrm{ACH}$ into a wider context, compare it with other hypotheses for AD, explore the evolution of the hypothesis to encompass new findings, and determine, irrespective of the merits of the hypothesis itself, whether it has been useful for the research field, both in academia and in industry. Finally, we shall review how the $\mathrm{ACH}$ has led to a number of therapeutic approaches, all of which have, to date, failed to reach their primary efficacy end-points in clinical trials and reflect upon what the future may hold.

\section{The hypothesis}

The major support for the $\mathrm{ACH}$ comes from the combination, and interdigitation, of pathophysiology and human genetics. The origins of the $\mathrm{ACH}$ lie in the sequencing of the amino acid sequence of $A \beta$ extracted from cerebral blood vessels (Glenner \& Wong 1984b) and then brain parenchyma (Masters et al. 1985) of post mortem brains from AD patients. This led to the identification and sequencing of the amyloid precursor protein (APP) gene (Kang et al. 1987) that encodes the holoprotein from which the $A \beta$ peptide is excised by the sequential action of $\beta$-amyloid cleaving enzyme (BACE) to release the $\mathrm{N}$ terminus of $A \beta$ (Hussain et al. 1999, Sinha et al. 1999, Vassar et al. 1999, Yan et al. 1999, Lin et al. 2000) and $\gamma$-secretase that cleaves at the C-terminus (De Strooper et al. 1998, Wolfe et al. 1999b). $\gamma$-secretase is a multi-protein complex comprised of Presenilin (PS)1 or PS2; aph1a or aph1b; Pen2 and nicastrin (for review, see (De Strooper et al. 2012)) with the PS proteins incorporating the enzyme's active site aspartyl resides (Wolfe et al. 1999a, Wolfe et al. 1999b). Although other publications were articulating similar viewpoints, (Hardy \& Allsop 1991, Selkoe 1991, Beyreuther \& Masters 1991), the ACH was expounded most trenchantly in 1992 (Hardy \& Higgins 1992). In this admirably brief paper, the deposition of the $A \beta$ peptide was portrayed as an upstream event in the evolution of $A D$, leading to cell death and/or the development of neurofibrillary tangles (NFTs) (hyper-phosphorylated, insoluble tau aggregates) via elevation of intracellular calcium ion levels. A critical component of the $\mathrm{ACH}$ comes from 
human genetics, where a family history of early onset $A D$ led to a linkage analysis study that revealed a mutation resulting in a $\mathrm{V} 717 \mathrm{I}$ amino acid change in the $A P P$ gene just $\mathrm{C}$-terminal to the $A \beta$ peptide sequence (Goate et al. 1991). This seminal work revealed that a single mutation resulted in early onset $A D$ that was pathologically identical to sporadic, late onset $A D$. The potential for a genetic cause for $A D$ had been made previously: in 1984, Glenner and Wong made the prescient observation that because the $A \beta$ peptide deposited in the cerebrovasculature of elderly Down's syndrome (Trisomy 21) subjects was identical (bar an experimental error at one position) to the 21 amino acids that were sequenced from sporadic $A D(S A D)$ patients, a genetic defect on chromosome 21 was likely to be a cause of $A D$ (Glenner \& Wong 1984a).

$A \beta /$ amyloid pathology is seen in all $A D$ patients, by definition, although its relationship to cognitive decline is unresolved (Arriagada et al. 1992, Delacourte et al. 1999, Naslund et al. 2000). There are now hundreds of mutations to three genes, PSEN1, PSEN-2 and APP that can cause early onset familial AD (FAD) (http://www.alzforum.org/mutations ). These mutations all have the effect of increasing the amount of $C$-terminally extended $A \beta$ peptides, or the ratio of aggregatory, longer forms of $A \beta$ to shorter, more soluble forms, or to increase the aggregatory properties of the $A \beta$ peptide directly (Citron et al. 1992, Suzuki et al. 1994, Scheuner et al. 1996, Borchelt et al. 1996, Duff et al. 1996, Bentahir et al. 2006, Hori et al. 2007, Inayathullah \& Teplow 2011, Ni et al. 2011, Chavez-Gutierrez et al. 2012, Szaruga et al. 2015). The longer forms of $A B$ are extended at the $C$-terminus with hydrophobic amino acids that greatly increase the propensity for aggregation (Jarrett et al. 1993). At this time, several groups made the critically important discovery that $A \beta$ was a regular secretion product from cells that expressed the $A P P$ gene rather than being produced solely under unusual or physiologically stressful conditions (Shoji et al. 1992, Haass et al. 1992, Seubert et al. 1992): this breakthrough enabled the development of cellbased assays to screen for compounds to inhibit $A \beta$ production. Ultimately, cell based assays were used in the discovery of $\gamma$-secretase inhibitors: competitive (Shearman et al. 2000, Esler et al. 2000, Li et al. 2000); non-competitive (Dovey et al. 2001, Lanz et al. 2006)) and modulator compounds (Weggen et al. 2001). The FAD mutations all localize to proteins involved in the production and properties of the $A \beta$ peptide. With respect to SAD, the greatest genetic risk factor is Apolipoprotein (APOE) 4 (Corder et al. 1993). The human population has three major alleles of $A P O E-A P O E 2, A P O E 3$ and APOE4 (Nickerson et al. 2000). One allele of APOE4 increases the risk of AD four-fold compared to an APOE3/APOE3 genotype; two copies of $A P O E 4$ increases the risk approximately 12 -fold and the APOE2 allele reduces risk compared to APOE3 (Verghese et al. 2011). While the biology of ApoE is undoubtedly complex (Liu et al. 2013, Holtzman et al. 2012), there is very strong evidence that show that ApoE is required for the deposition of amyloid from preclinical (Bales et al. 1999, Holtzman et al. 2000, Holtzman et al. 1999) and clinical (Schmechel et al. 1993, Jack et al. 2015)studies. Moreover, the increased probability of having brain amyloidosis matches the ApoE isoform dependent risk of succumbing to AD. Additional evidence for the primacy of the role of $A \beta$ in $A D$ comes from the A673T mutation (Jonsson et al. 2012) that significantly protects against $A D$. This mutation (Figure 1 ) decreases both the production and aggregatory properties of $A \beta$ (Maloney et al. 2014, Benilova et al. 2014).

In summary, the $\mathrm{ACH}$ accommodates a wide range of data that we have on $\mathrm{AD}$ into a coherent hypothesis. It is worth articulating three tenets that have to be true if ultimately we will refute the null hypothesis. 
1. The parenchymal deposition of the $A \beta$ peptide is important pathophysiologically.

2. $A \beta$ peptide deposition occurs prior to the frank neuronal and synaptic loss that is the hallmark of $A D$.

3. The evidence from mutations that cause FAD is informative and relevant to SAD.

Taking each in turn, (1) is to a certain extent a matter of semantics. As a definite diagnosis of $A D$ relies on neuropathologic evidence revealing $A \beta$ plaques and NFTs, presence of deposited $A \beta$ peptide is by definition required. However, the role of deposited $A \beta$ peptide as being the preeminent disease-causing $A \beta$ species has been brought into question by the burgeoning literature on smaller molecular weight oligomeric $A \beta$ (oA $\beta$ ) (see later). Thus, it could be argued that the deposition of $A \beta$ is irrelevant to the disease process as such, or at least of much lesser importance. (2) is likely true although now open to a different interpretation. The $\mathrm{ACH}$ as originally conceived placed amyloid as upstream of tau pathology, and yet detailed neuropathological studies have shown that tau pathology is present from a very early age in some people and in all cases precedes amyloid pathology (Braak et al. 2011). However, correlative studies have shown that amyloid pathology likely drives tau pathology from restricted allocortical sites to proliferate throughout the cortex leading to widespread neuronal loss (Price \& Morris 1999). (3) is still a matter of significant debate, but it seems very likely that the familial and sporadic forms of the disease are identical in all major respects. For example, the neuropathology of SAD and FAD are indistinguishable from each other (Nochlin et al. 1993, Lippa et al. 1996). Thus, for the diseases to be fundamentally different, it would be necessary to explain why the pathological changes in a FAD brain lead to a different disease process than in a SAD brain. Furthermore, as stated previously, the greatest genetic risk factor for SAD is carrying an APOE4 allele which also brings forward the age of onset for the disease (Corder et al. 1993). In very large cohorts of FAD patients that all carry the same PSEN1 mutation, it has been demonstrated that the APOE4 allele also brings forward the age of onset (Pastor et al. 2003). If SAD and FAD were very different diseases, it would be unlikely that they would both be subject to the same genetic modifier.

Before exploring some of the deficiencies in the $\mathrm{ACH}$, it is worth briefly considering alternative hypotheses that have been posited for the onset and progression of $A D$.

Mitochondrial cascade hypothesis

The mitochondrial cascade hypothesis $(\mathrm{MCH})$ posits that age-related mitochondrial dysfunction ultimately leads to the pathology and symptomatology of AD (Swerdlow \& Kahn 2004, Swerdlow et al. 2014). It also attempts to resolve the difficult question of whether SAD is a usual, but not necessarily universal, consequence of brain aging. Indeed, in very elderly cohorts the prevalence of AD pathology may exceed 50\% (Polvikoski et al. 2001). There is little doubt that there is evidence of mitochondrial damage in the brains of people suffering from AD (Lin \& Beal 2006). Furthermore, fluorodeoxyglucose positron emission tomography (PET) imaging has revealed deficits in the AD brain quite early on in the disease process, which as a marker of oxygen uptake is likely affected due to alterations in mitochondrial function (Jack et al. 2012). Also, there is abundant evidence of increases in free radical damage in $A D$ brains that again might result from dysregulated mitochondrial function (Sonnen et al. 2008). Some of the experimental support for the $\mathrm{MCH}$ comes from the use of cybrids which is where a cell line is treated with ethidium bromide to block mitochondrial DNA replication to from a ' $\mathrm{p} 0$ ' cell. 
These cells are then co-cultured with platelets from a human host (e.g., with $A D$ ) in the presence of polyethylene glycol that induces the transfer of platelet mitochondria into the 00 cells to form a cybrid (King \& Attardi 1989) - a cell containing mitochondria from a different cell. Experiments with AD cybrid cells have shown an increase in $A \beta$ production (Khan et al. 2000) and reactive oxygen species (Cardoso et al. 2004). The $M C H$ uses such data to suggest that a mitochondrial deficiency in $A D$ brains underpins an increase in $A \beta$ production. In the $\mathrm{MCH}, \mathrm{A} \beta$ is a biomarker for brain aging, but not a cause of $A D$ as such.

In our opinion, the MCH fails to answer some key questions. Despite very large genome wide association studies (GWAS), no genes that encode mitochondrial proteins or proteins involved in bioenergetics have been found (Lambert et al. 2013). Some of the evidence in support of the MCH comes from cell biological systems that are significantly manipulated and might not reflect the human pathophysiological situation. For example, demonstrating that cybrid cell cultures show an increase in $A \beta$ production does not reflect the situation in $S A D$, or, in most cases, in FAD, where the majority of mutations alter the ratio of $A \beta$ metabolites or their propensity to aggregate, but do not increase the absolute amount - indeed, many reduce overall $A \beta$ production (Chavez-Gutierrez et al. 2012, Szaruga et al. 2015). The MCH fails to account for the A673T mutation in APP (Jonsson et al. 2012) that has been demonstrated to protect against $S A D$ by reducing $A \beta$ production modestly and reducing its propensity to aggregate (Jonsson et al. 2012, Benilova et al. 2014, Maloney et al. 2014). One of the tenets of the MCH, that $A D$ is largely a disease of aging, can also be questioned on several levels. For example, none of the genes that causes FAD is known to play a role in aging, and none of the mutations that causes progerias results in accelerated AD pathology (Nelson et al. 2011). Critically, the $\mathrm{MCH}$ does not articulate how mitochondrial dysfunction leads to the full panoply of AD pathology, which is something it shares in common with the $\mathrm{ACH}$.

Dual Pathway Hypothesis.

The dual pathway hypothesis (DPH) (Small \& Duff 2008) seeks not to refute the ACH as such, but more to refine it especially insofar as SAD is concerned. Part of the motivation for so doing is based on the failure of drugs targeting amyloid (amyloidocentric) to provide therapeutic benefit. In fact, from the time the DPH was published, the litany of failure for amyloidocentric drugs has significantly worsened (Karran \& Hardy 2014, Cummings et al. 2014). Post mortem data from patients that participated in the Phase 1 AN1792 study (Nicoll et al. 2003, Holmes et al. 2008, Paquet et al. 2015), where amyloid was apparently cleared from the brains of patients but cognitive decline proceeded unabated, is used to support the view that amyloid deposition in SAD does not necessarily drive other pathologies, as is implicit in the $\mathrm{ACH}$. The DPH posits that there might be upstream factors that are able to drive both the major pathologies, amyloid and tau, such that treatments downstream of these factors will not ultimately provide therapeutic benefit. The data supporting potential upstream mechanisms includes, for example, ApoE4, which might act to increase $A \beta$ deposition via reduced clearance and increase tau phosphorylation via low-density lipoprotein receptor related protein (LRP) 5 and LRP6 signaling to activate glycogen synthase kinase $3 \beta$ activity.

However, and as pointed out by the authors, the data supporting ApoE4 mediating its effects via $A \beta$ are very compelling and more substantive than are the links to tau pathobiology. Further, the phenotypic 
effect of ApoE4 to bring forward the age of onset for $A D$ is present in both SAD and FAD (Pastor et al. 2003), strongly implying that $S A D$ and FAD are similar disease processes. Finally, from neuropathological and clinical correlations, tau pathology is better correlated with both neuronal loss and symptomatology (Arriagada et al. 1992, Gomez-Isla et al. 1996). If ApoE4 was driving both pathologies, one might anticipate that ApoE4 would bring forward the age onset of disease and accelerate disease progression: while there is excellent evidence for the former, there are little data to support the latter. Nevertheless, the DPH seeks to resolve the disconnection between amyloid and tau pathology and to explore the upstream triggers for disease in SAD, which is totally unexplained by the $A C H$.

\section{The Metabolism Hypothesis}

The metabolism hypothesis (MH) has its origins the work of Hoyer and colleagues (Hoyer et al. 1988, Hoyer 1991) who believed that the underlying cause of AD was cerebral glucose hypometabolism. To investigate this phenomenon they developed a rat model that involved injecting streptozotocin intracerebroventricularly into rats (Lannert \& Hoyer 1998). This resulted in decreased glucose/energy brain metabolism together with learning and memory deficits. Streptozotocin is an agent widely used in the diabetes field to destroy $\beta$ pancreatic cells in rats to produce an insulin-dependent diabetic state. Since these early experimental approaches, a significant body of evidence has grown that indeed establishes that insulin signaling in the brain is significantly impaired. For example, many of the mRNA transcripts encoding key elements of the insulin signaling pathway are significantly depressed in multiple regions of the AD brain (Steen et al. 2005) leading to the description that AD is 'Type 3 Diabetes'. Proponents of the $\mathrm{MH}$ argue that insulin signaling is required for preserving synaptic connectivity and may play a role in neuronal stem cell activation and neuronal 'resilience'. Some very interesting preclinical work has been performed with incretin mimetics such as liraglutide, which when administered via intraperitoneal injection to APP Swe $/ P S 1 \triangle E 9$ mice $(25 \mathrm{nmol} / \mathrm{kg}$ od) was shown to reduce $A \beta$ plaque load significantly (McClean \& Holscher 2014). There are also data that show that $A \beta$ oligomers $(O A \beta)$ bind to and antagonize various components of the insulin signaling pathway and that this may lead to an increase in activity of GSK-3 $\beta$, a known tau kinase (Morgen \& Frolich 2015).

Furthermore, as stated earlier, imaging studies using fluorodeoxyglucose PET brain imaging, which is a measure of glucose uptake and neuronal activity, reveals deficits very early on in the clinical course of AD patients (Jack et al. 2011).

It is difficult to extrapolate the findings from the streptozotocin rat experiments to AD: there is very little face or construct validity given the relatively non-specific mechanism of action of the toxin. The role of $\mathrm{OA} \beta$ to provoke insulin signaling abnormalities is rather weak, mainly because the role of $\mathrm{A} \beta$ themselves is controversial (Benilova et al. 2012). It is difficult to assign a primary role of insulin signaling abnormalities in disease causation as currently there are no data from GWAS studies to support such a role (Lambert et al. 2013), and the data that place insulin signaling abnormalities upstream of tau and amyloid pathology are not yet compelling. It may be the case, however, that insulin signaling pathways are adversely affected due to the AD disease process itself, and in general this hypothesis has merit because it provides a number of testable hypotheses and avenues for therapeutic intervention. Indeed, there have been a number of small clinical experiments where insulin has been delivered directly intra- 
nasally into the brain with promising results (Bedse et al. 2015, Craft et al. 2012), leading to a much larger clinical trial that is underway (ClinicalTrials.gov Identifier:NCT01767909).

\section{Cell-Cycle Re-entry Hypothesis}

The cell-cycle re-entry hypothesis (CCRH) might be considered a particular form of a more general hypothesis that posits that an age-related increase in DNA damage in neurons is responsible for neurodegenerative disease (Chow \& Herrup 2015). Neurons are post-mitotic cells and therefore need to sustain their genomic integrity for life. Neurons might also be subject to significant stressors during life: being cells with a very high energy requirement, the potential for DNA damage via reactive oxygen species is significant coupled with the errors that can result from gene transcription (Poduri et al. 2013, Lodato et al. 2015). The first indications of a potential role for aberrant cell cycling in the brain came from observations demonstrating that mitogen kinases had increased expression in the AD brain (Arendt et al. 1995) and that specific antibodies raised to paired helical filaments (PHFs) of tau purified from AD brain cross-reacted with epitopes in dividing cells (Vincent et al. 1996). Further work revealed that driving primary, differentiated neurons to divide by infecting with oncogenes c-myc and ras resulted in DNA duplication and increases in both anti-phospho-tau immunoreactivity and AD-like abnormally folded tau epitopes (recognized by ALZ50 antibody) (McShea et al. 2007). However, the cells did not enter mitosis, suggesting that the cells get blocked at the G2/M transition. The c-myc oncogene was also conditionally expressed in frontal cortex using CaMKII-tTa transgenic mice crossed to tet-o-Myc transgenic mice (Lee et al. 2009). c-Myc expression was initiated by removing doxycycline from the diet. The bigenic mice showed markers of cell cycle activation, DNA replication, hippocampal neuronal loss and cognitive behavioral deficits. Surprisingly, given previous work, evidence for abnormal tau phosphorylation was not presented. In post mitotic neurons, DNA repair is afforded by a variety of mechanisms which if disrupted can result in a number of serious neurological abnormalities including neurodegeneration (McKinnon 2013) but these are mostly early onset developmental conditions. Linking frustrated mitotic cell division to the range of neuropathology evident in $A D$ is currently challenging. While a plausible link to tau pathology can be made, the data suggesting a role for cell cycle re-entry in $A \beta$ deposition is not substantial. Further, there is currently no human genetic evidence from GWAS studies that support a role for aberrant cell-cycle re-entry (Lambert et al. 2013), and it is difficult to reconcile the effect of the A673T APP mutation to protect against AD into this schema (Jonsson et al. 2012).

\section{Vascular hypothesis}

The vascular hypothesis $(\mathrm{VH})$ was originally based on the neuropathological observations that the $A D$ brain has a disorganized and much reduced capillary and vascular network (Fischer et al. 1990, de la Torre \& Mussivand 1993). There is now a significant body of evidence that supports an important role for the brain's vascular system in AD (de la Torre 2004, Marchesi 2011). Some of the known risk factors for $A D$ include hypertension in midlife and diabetes in late-life (and probably in midlife) both of which have significant vascular morbidities (Prince et al. 2014). A study of the localization of thioflavine Tstaining amyloid plaques in a range of dementias (AD, Pick's disease, Guam amyotrophic lateral 
sclerosis/parkinsonian dementia complex, Down syndrome, dementia pugilistica and prion disease) revealed significant reductions in the microvasculature and some co-localization of blood vessels and plaques (Buee et al. 1994). This latter aspect was investigated more thoroughly and the co-localization of haem-rich deposits, amyloid plaques and blood vessels was demonstrated in AD and Down's syndrome brains (Cullen et al. 2006). A very thorough investigation of this relationship was performed using the TG2576 and the PSAPP transgenic mouse models that both develop parenchymal amyloid deposition (Kumar-Singh et al. 2005). These studies revealed that $85-95 \%$ of dense core plaques were either centered on, or adjacent to, vasculature vessel walls. Interestingly, the same was not true for diffuse amyloid. However, in both these models the $A \beta$ composition of the plaques is dominated by the $A \beta 40$ species, unlike $A D$ plaques which are made predominantly of $A \beta 42$ (Welander et al. 2009). $A \beta 40$ is more soluble than the $A \beta 42$ and more likely to be able to be trafficked to the vasculature via bulk interstitial fluid flow. However, these studies cannot confirm a temporal relationship - do amyloid plaques result in vascular damage, or does vascular damage result in plaques? To investigate this aspect, the generation of plaques was investigated using electron microscopy and the earliest signs of fibrillary $A \beta$ appeared to form in the perivascular space. This work relates importantly to the clearance of $A \beta$ from the brain: clearly, if extracellular concentrations of $A \beta$ are kept low, the potential for aggregation will likely be diminished. A detailed analysis of brain clearance mechanisms is beyond the scope of this review (see (Weller et al. 2008, Tarasoff-Conway et al. 2015)) but there have been some recent important developments. A clearance pathway - the glymphatic system - has been described for the first time (lliff et al. 2012) that is part of the $A \beta$ clearance mechanism. The glymphatic (gliallymphatic) system consists of perivascular conduits formed by glial cell end-feet. Interestingly in the context of $A D$, these glial processes are also a site of ApoE expression. Fluid is believed to be impelled through the glymphatic system at least in part by the pulsatile contraction of smooth muscle cells in the vasculature, providing a potential mechanistic link with the vascular system. There are several aspects of the $\mathrm{VH}$ that integrate multiple elements of features of $\mathrm{AD}$ : the known co-morbidities, the important role in $A \beta$ clearance and providing potential sites for initial $A \beta$ deposition. However, what is difficult to determine is primacy of effect. Does a vascular insufficiency leading to impaired $A \beta$ clearance, or local vascular damage, provide the appropriate local environment for amyloid deposition, or does amyloid deposition result in vascular damage: or can it be both?

\section{$A \beta$ Oligomer Hypothesis}

The $A \beta$ Oligomer Hypothesis $(A B O H)$ is a variant of the original $A C H$ that currently has significant momentum (Walsh \& Selkoe 2007). The $A B O H$ posits that small molecular weight oA $\beta$ represent neurotoxic agents that cause synaptic damage in $A D$. There are significant attractions to the $A B O H$, principle amongst which is a potential resolution of a major conundrum of $A D$ research: amyloid plaques do not correlate in terms of their amount, nor brain regional location, with $A D$ symptomatology or neuronal loss (Gomez-Isla et al. 1996, Delacourte et al. 1999). Indeed, it is difficult to visualize how very insoluble, relatively inert protein deposits are able to exert a damaging effect on the brain. Thus, oA $\beta$ might act at a distance from plaques and mediate toxic effects. There are wealth of data, beyond the scope of this review, that together provide a large body of supportive data for the $\mathrm{ABOH}$. These include: the manufacture of various aggregated forms of $A \beta$ in vitro, using $A \beta 42, A \beta 40$, ratios, and modified 
forms thereof at supra-physiological concentrations to make oA $\beta$; the profiling of these using analytical techniques such as size exclusion chromatography, sodium dodecyl sulfate - poly acrylamide gel electrophoresis gels (SDS-PAGE) and EM imaging; the treatment of in vitro neuronal cell cultures with (usually) supra-physiological concentrations to induce neuronal cell distress; the investigation of oA $\beta$ to affect a number of important neuronal receptors (eg, Insulin R, nicotinic receptors); the treatment of brain slice preparations to induce electrophysiological changes such as reduction or abolition of LTP; the injection of $O A \beta$ into rodent brains to induce impaired cognitive functioning (Haass \& Selkoe 2007,

Ferreira \& Klein 2011, Koffie et al. 2011, Mucke \& Selkoe 2012, Hayden \& Teplow 2013, Hefti et al. 2013, Viola \& Klein 2015). Also, there have been attempts to categorize oA $\beta$ in APP transgenic mice using anti$\mathrm{OA} \beta$ conformational antibodies (Liu et al. 2015). The $\mathrm{ABOH}$, if true, would also have a profound effect on clinical development, as it could mean that therapeutics that are targeting amyloid plaque would not be efficacious, and indeed might be positively deleterious if by disaggregating plaques they released, or created favourable conditions for, increased levels of $O A B$. Despite these data, and significant support in the $A D$ research field generally, there a number of fundamental questions that remain to be answered with respect to the $\mathrm{ABOH}$ (Benilova et al2012). Hepler and colleagues (Hepler et al. 2006) have shown convincingly that aggregated $A \beta$ runs aberrantly in size exclusion chromatography, mainly because monomeric $A \beta$ does not perform as a solvated sphere. Further, these workers have shown SDS-PAGE cannot be used to resolve different $A \beta$ species unequivocally, and also that the appearance of oA $\beta$ in electron microscopy is heavily dependent on the properties of the surface upon which the $A \beta$ aggregates are dispersed. Thus, many analytical procedures routinely used in the field are confounded. The interpretation of neuronal cell death induced by $\mathrm{OA} \beta$ in vitro is also problematic. Often, such experiments use neuronal cell lines or primary rodent neurons to demonstrate $A \beta$-mediated cell distress and death, sometimes in a manner that discriminates between different $\mathrm{OA} \beta$ forms (Ono et al. 2009, Ahmed et al. 2010). However, in APP transgenic mouse models, which reveal plaque pathology that is very similar to that seen in AD, neuronal loss is usually completely absent (Irizarry et al. 1997a, Irizarry et al. 1997b). Thus, human $A \beta$ can be toxic to rodent neurons in vitro, but often not in vivo.

The most challenging of these questions is to provide unequivocal evidence of their existence, and role, in the $A D$ brain. Attempts to measure $O A \beta$ in intercellular fluid in brain parenchyma of transgenic mice that develop $A \beta$ plaque pathology have been very technically challenging (Hong et al. 2014) as have measurements of $O A \beta$ in cerebrospinal fluid from $A D$ patients. Indeed, recent work with sensitive assays has failed to reveal a difference between oA $\beta$ concentrations in $A D$ versus controls (Yang et al. 2015).

These studies have been confounded by a lack of a biophysical definition of an oligomer and no standard preparation of a single species with which to calibrate and control assays. It is important, in this context, to distinguish between measuring $O A \beta$, and extracting $\circ A \beta$. There are multiple papers that use various techniques to extract a range of $O A B$ species from $A D$ brains that can be subsequently revealed on denaturing SDS-PAGE, followed by Western blotting using anti-A $\beta$ antibodies (Ward et al. 2000, Upadhaya et al. 2012). However, these techniques likely create $\mathrm{OA} \beta$ species due to the physicochemical properties of the $A \beta$ peptide as discussed earlier. Leaving aside these issues, perhaps the most compelling evidence for a role of $\mathrm{OA} \beta$ could be inferred from human genetics - indeed, the V717I mutation that causes FAD provided the cornerstone for the amyloid cascade hypothesis (Goate et al. 1991). The APP gene has a wide range of different mutations (http://www.alzforum.org/mutations) that cause FAD and/or congophilic amyloid angiopathy (Figure 1). These can be either $\mathrm{N}$-terminal or $\mathrm{C}$ - 
terminal to, or within, the $A \beta 42$ peptide. A consideration of the latter is particularly instructive because these are unlikely to affect the production of $A \beta$ or the ratio of long to shorter forms that has been shown previously to be important in age of disease onset (Duering et al. 2005, Kumar-Singh et al. 2006). Mutations within the $A \beta 42$ peptide are more likely to affect the folding of the peptide, although other aspects may also be affected, such as clearance from or degradation within the brain. However, a mutation that locked the $A \beta$ peptide in an $O A \beta$ from, or greatly inhibited the formation of amyloid fibrils so as to increase the proportion of $O A \beta$, would add significant weight to the $A B O H$.

The amino acid position 2 of the $A \beta$ sequence (with the $N$-terminal $A \beta$ aspartic acid $=1$ ) is particularly interesting as it has both protective (A2T) (Jonsson et al. 2012) and disease-causing (A2V) mutations (Di Fede et al. 2009) (Figure 1). A2T results in a 50\% reduction in A $\beta$ production when over-expressed in primary mouse neuronal cells, which would equate to a $25 \%$ reduction in the heterozygotic state (Benilova et al. 2014). A2V, found as an autosomal recessive mutation in humans, approximately doubles production of $A \beta$ by rendering APP a better substrate for $\beta$-secretase. However, both mutations also have effects on the aggregatory properties of the $A \beta$ peptides that were revealed using synthetic $A \beta 40$ preparations. Effects on $A \beta 42$ were not informative for largely technical reasons: at the concentrations of $A \beta$ used in these experiments, $A \beta 42$ forms amyloid fibrils very rapidly compared to $A \beta 40$ making dissection and measurement of aggregation very challenging. The protective A2T mutation increased the lag phase prior to aggregation and the change in Gibbs free energy compared with wild type was lower, demonstrating the reduction in aggregation. The A2V mutation almost abolished the lag phase, such that fibrillar amyloid was being formed almost immediately. Interestingly, antibodies that have been reported to be conformational, 'OA $\beta$ specific' (A11 and OC) (Kayed et al. 2007) failed to recognize either mutant $A \beta$ in the soluble phase post-fibrillization despite a range of small $A \beta$ species being visualized using electron microscopy. This finding rather casts doubt on the validity of these antibodies to measure $O A \beta$ specifically. Similar work was published using $A \beta 42$ peptides (Maloney et al. 2014). Hori and colleagues (Hori et al. 2007) studied the effects of the H6R, D7N and E22G mutations. All the mutations increased the rate of formation of fibrillary amyloid, but this was mediated differently. In the case of E22G, both seeding/nucleation and amyloid fibril elongation was increased significantly compared to wild type $A \beta$. This led to increases both in protofibril and fibril formation. The effects of the H6R and D7N mutations were to increase significantly amyloid fibril enlongation rate - that is, the rate at which monomers are added to the growing amyloid fibril. However, this led to very significant reduction in the concentration and residence time of oA $\beta$ species: presumably, the addition of monomers to existing amyloid fibrils was energetically more favourable than the formation of $O A \beta$ and protofibrils.

The $\triangle \mathrm{E} 22$ mutation initially caused significant excitement in the field because the first reports suggested that the phenotypic effect was to promote oA $\beta$ formation and prevent A $\beta$ fibril formation (Tomiyama et al. 2008). However, subsequent work revealed that this was likely an assay artefact (Inayathullah \& Teplow 2011). The effects of the $\Delta E 22$ mutation are two-fold: firstly, there was an increase in the formation of $O A \beta$ species. However, this effect was dwarfed by an extraordinary increase in the propensity of the mutant to form $\beta$-pleated sheet fibrillar amyloid that was $\sim 400$-fold faster than wild type.

A comparative study of the A21G, E22G, E22Q, E22K and D23N mutations ( $N$ i et al. 2011) showed that all of these species were able to form $\beta$-pleated sheet amyloid fibrils. With the exception of A21G, all of the 
mutants decreased the lag phase for the formation of $A \beta$ fibrils, some of them dramatically (E22Q, D23N). A21G resulted overall in an increase in total fibrillization, as did E22Q. It is important to note that these mid-domain changes may have other effects as well: for example, these mutations can cause cerebral amyloid angiopathy as well as AD, implying changes in clearance mechanisms (Van Broeckhoven \& Kumar-Singh 2006, Zhang-Nunes et al. 2006).

In conclusion, the effects of the mid-domain $A \beta$ mutations on aggregation do not provide data in support of the $\mathrm{OABH}$, although caution is warranted in extrapolating from very artificial biochemical systems to the complexity of the human brain. Nonetheless, if anything the mid-domain mutations tend to increase the propensity of $A \beta$ to form amyloid rather than $O A \beta$. A compelling role for oA $\beta$-type species is in the seeding of amyloid plaques. A wealth of careful and compelling science from Walker and Jucker, and others, have unequivocally demonstrated that a soluble $A \beta$ species is able to seed $A \beta$ plaque deposition (for review, see (Walker \& Jucker 2015). Furthermore, these species are very stable, long lived and prion-like (Ye et al. 2015). The seeding of $A \beta$ plaque in humans has also recently been postulated as a consequence of the treatment of humans with extracts from pituitary glands (Jaunmuktane et al. 2015) or with dura mater grafts (Frontzek et al. 2016) although caution must be exercised in interpreting these data given the very heterogeneous nature of the implanted tissues.

For each of the hypotheses considered here, including the $\mathrm{ACH}$, rejection of the null will require firstly, the development of a specific therapeutic approach that addresses a key mechanism that is predicted by the hypothesis to be pathological, and secondly, the demonstration that the therapy has efficacy in a placebo-controlled, randomized clinical trial in AD patients. Also, it is important to distinguish between the causes of $A D$, and the consequences of the AD process. It is likely that many of the processes that are featured in the various hypotheses previously considered do play a role in $A D$, but they do not initiate the disease.

A version of the ACH hypothesis is provided ( Figure 2) that we believe reflects, parsimoniously, the current state of knowledge. There are still a significant number of gaps in the ACH, many of which have been attacked by detractors of the hypothesis (Herrup 2015) and that we will address where possible.

Disease initiation

In $S A D$ and FAD we do not know what initiates $A \beta$ deposition. The $A C H$ has sometimes been interpreted to suggest an increase in $A \beta$ production results in $A D$, and indeed there are data that support this view (Potter et al. 2013) but in fact the majority of FAD mutations do not result in an increase in A $\beta$ production, but an increase in the ratio of the longer to the shorter forms of the $A \beta$ peptide (Citron et al. 1992, Suzuki et al. 1994, Scheuner et al. 1996, Borchelt et al. 1996, Duff et al. 1996, Bentahir et al. 2006, Chavez-Gutierrez et al. 2012, Szaruga et al. 2015). Also, $A \beta$ is not present at a concentration in interstitial fluid at which it can spontaneously aggregate, so it must be a facilitated process. However, there is compelling data that very low abundance, stable, $A \beta$ conformers can seed $A \beta$ plaques as previously discussed. This opens the possibility that a very discrete, local increase in $A \beta$ concentration, or a stochastic templating event, could create seeds that ultimately catalyze widespread plaque 
deposition. Quite possibly, and as mentioned previously, the microvasculature, or the glymphatic system, may play important roles in this regard.

Why is not FAD a neurodevelopmental disease?

The mutations that result in FAD are present throughout life but nevertheless have a relatively late age of onset. The explanation for this is likely to reside in some element of brain physiology that changes with age and offsets or prevents the initial $A \beta$ seeding event. For example, several relevant homeostatic mechanisms, such as the production of CSF (Rubenstein 1998) and proteostasis decline with age (Labbadia \& Morimoto 2015), and these, and other mechanisms, could lead to a catastrophic seeding event. The same argument can be made for $S A D$ albeit at a later age. In this model, initial A $\beta$ seeding is a feature of the aggregatory properties of the $A \beta$ peptide coupled to the brain's compensatory mechanisms.

Why is there no correlation between the levels of amyloid $A \beta$ and cognitive impairment?

This issue can be partly understood from the effects of FAD mutations and APOE4 genotype, the effects of which are to bring forward, in some cases dramatically, the age of onset of AD but not to accelerate the progression of the disease. This situation is concordant with amyloid $A \beta$ either triggering a disease process, or surmounting some threshold before the disease is provoked (reviewed in (Karran et al. 2011)). In this case, one would not expect a correlation between $A \beta$ amyloid and cognitive decline. Another way of thinking about this question is to consider that AD pathology - both amyloid and tau can be accommodated by the brain by cell driven compensatory mechanisms until there is a deleterious cellular response that leads ultimately to system failure (De Strooper \& Karran 2016).

What is the connection between amyloid and tau pathologies?

The $\mathrm{ACH}$ has no answer to this question currently, and in Figure 2 this is represented by 'aggregate stress'. However, there are some very intriguing trends. The discovery that mutations to TREM2 are very significant risk factors for AD place the microglial cell centrally in the disease process (Guerreiro et al. 2013, Jonsson et al. 2013), an observation that others have made well before the genetic evidence was known (McGeer et al. 1988). TREM2 is a type I transmembrane protein that is expressed on microglia. A study of late onset AD patients versus controls using whole-genome gene-expression profiling (Zhang et al. 2013) demonstrated that a module grouping innate immunity/microglia related genes correlated best with clinical disease. TYROBP ranked highest as the module's potential regulator. TYROBP, otherwise known as DAP12, encodes the signalling partner for TREM2. Thus, from two orthogonal data sources the TREM2/Tyrobp signaling system has been implicated in AD. Homozygous, loss of function mutations in TREM2 and TYROPB cause Nasu Hakola disease that is characterized by cystic bone lesions, white matter loss and dementia. TREM2 binds to a range of poorly defined ligands such as phospholipids, bacterial products and cell debris and receptor binding mediates microglial phagocytosis and promotes an anti-inflammatory cytokine profile (Daws et al. 2003, Cannon et al. 2012). The greatest risk for $A D$ is associated with the $\mathrm{R} 47 \mathrm{H}$ variant which causes loss of function by preventing

Commented [BDS1]: In our cell review we argue that it is possible that Tau pathology needs to be established before AD can install itself

Also in your drawing you imply that the two pathologies develop independently to interact at a critical phase 
normal folding of the protein (Kleinberger et al. 2014). An obvious hypothesis is that TREM2 signalling plays a role in the balance of pro-inflammatory responses versus phagocytosis of $A \beta$ plaques (Kleinberger et al., 2014).

A series of GWASs studies has ultimately resulted in the identification of 22 susceptibility loci (Lambert et al. 2013) of which a large group clearly are related to innate immune system regulation: complement receptor 1 (CR1), clusterin, CD33, the MS4A6-MS4A4 cluster, ABCA7, CD2AP, EPHA1, HLA-DRB5-DRB1, INPP5D and MEF2C (Karch and Goate, 2014). It is feasible that as the effects of these genes on biological systems is unravelled, a pathway between amyloid and tau pathology will be found, and may reside in the brain's inflammatory response to amyloid deposition.

\section{The $\mathrm{ACH}$ can be rejected because amyloidocentric drugs have failed}

It a matter of great concern, both to adherents of the $\mathrm{ACH}$ and its gainsayers, that none of the amyloidocentric drugs tested to date has met their predetermined primary endpoints. However, it is one thing to test a drug and quite another to test a hypothesis. In a thorough review of the recent amyloidocentric drug discovery and development programs that have reached Phase 3 clinical testing (Table 1) it was shown that in several cases there was a significant lack of translation from preclinical to clinical science, and in only two of the programs - semagecestat and solanezumab - was target engagement measured (Karran \& Hardy 2014). However, there has been no doubt that this catalogue of failure (Cummings et al. 2014) has been damaging: while several cogent arguments can and have been deployed to explain the lack of efficacy of these approaches (eg De Strooper, 2014), nevertheless the field may lose patience and the will to continue with amyloidocentric approaches in the absence of tangible success. The field has not been without some encouragement, however. Solanezumab was shown to have a significant effect on cognition in the Expedition and Expedition II trials in mild AD in a pre-specified secondary outcome (Siemers et al. 2015), and in a three year 'staggered-start' extension study following the initial blinded phase, there was evidence for a genuine disease-modifying effect (LiuSeifert et al. 2015) .

\section{Has the $\mathrm{ACH}$ been useful?}

Undoubtedly, it has. The $\mathrm{ACH}$ has provided a framework that has underpinned a huge amount of both academic and industry science. While Table 1 makes for sober reading, a huge amount of data and experience has been gathered regarding trial design, patient ascertainment, drop-out rates, placebo decline, biomarkers, and clinical assessment. Significant progress has been made in field of biomarkers in particular: it is difficult to imagine that the field would have initiated the AD Neuroimaging Initiative (Weiner et al. 2010, Weiner et al. 2015) and developed a number of amyloid PET ligands in the absence of the ACH. The field has learned from failure, although more data sharing, especially between pharmaceutical companies, would facilitate information dissemination significantly.

The field has re-defined $A D$ in recognition that amyloid deposition occurs many years prior to the onset of symptoms, such that there is now a phase called preclinical asymptomatic amyloidosis (Sperling et al. 2011). This change in perspective has prompted a significant number of clinical investigations into
Commented [BDS2]: Changed the sentence, was a bit too similar as asentence in our Cell review

Commented [BDS3]: Sorry for publicity De Strooper, B. (2014). Lessons from a Failed $y$-Secretase Alzheimer Trial. Cell 159, 721-726. 
presymptomatic patients - a move that would have been almost unimaginable not so many years ago, but one that is nevertheless supported by our growing understanding of the disease (Reiman et al. 2016).

The future: are we poised for success or failure?

Table 2 gives the current status of amyloidocentric therapeutic approaches in the clinic - an impressive list. The field awaits with great anticipation the results from verubecestat and solanezumab which are the most advanced in clinical development. If either therapeutic meet their primary outcome measures, a huge amount of work, in academia and industry, would seem to have been worthwhile, and at long last $A D$ patients and those that care for them will have been given hope. But what if they fail? The effects of FAD mutations are unequivocally to bring forward the age of disease onset: yet there are little data to support the case that they accelerate the progression of the disease once initiated (Holmes \& Lovestone 2002, Godbolt et al. 2004, Snider et al. 2005, Kumar-Singh et al. 2006, Acosta-Baena et al. 2011, Karran et al. 2011). As FAD mutations likely all increase the probability of amyloid deposition, it could be the case that amyloid deposition triggers, but does not drive, the disease process. The long clinical silent phase between amyloid deposition and dementia suggest indeed a complicated process of cellular action and reaction, which we have called the cellular phase (De Strooper and Karran, 2016) and might lead to secondary, irreversible and damaging disturbances of normal brain homeostasis. Thus it is conceivable that amyloidocentric approaches may only provide therapeutic benefit if they are administered prophylactically in a primary prevention-type clinical trial. In the most challenging clinical scenario, and depending somewhat on the mechanism of action of the therapeutic, this would mean treating at-risk individuals prior to amyloid deposition and many years before any cognitive symptoms are manifest. If an amyloidocentric therapy failed to act in such a trial, and presuming that it demonstrated adequate target engagement, despite all of the supporting evidence for the $\mathrm{ACH}$, we would need to accept the null hypothesis. Clearly, we hope, and anticipate, that some of therapeutic approaches show efficacy well before this type of prevention study is completed. Realistically, it is unlikely that the current agents under phase 3 clinical testing will demonstrate outstanding efficacy, but to answer the question posed by the title of this review, we believe that for solanezumab at least we are poised for a modest therapeutic benefit, but a very large scientific success.

Table 1. Outcome of Phase 3 clinical trials of amyloidocentric drugs.

\begin{tabular}{|l|l|l|}
\hline Drug name & $\begin{array}{l}\text { Proposed mechanism of } \\
\text { action. }\end{array}$ & Phase 3 results \\
\hline Tramiprosate Aß & $\begin{array}{l}\text { Small molecule to prevent } \\
\text { A } \beta \text { aggregation. }\end{array}$ & $\begin{array}{l}1052 \text { mild to moderate AD patients randomized } \\
\text { to 3 groups: placebo, 100, 150mg/kg bid for } 78 \\
\text { weeks. No significant effects on primary outcome } \\
\text { measures of ADAS-cog and CDR-sum of boxes } \\
\text { (Aisen } \text { et al. 2011) }\end{array}$ \\
\hline Tarenflurbil & Small molecule $\gamma$-secretase & 1684 mild AD patients randomized to placebo, \\
\hline
\end{tabular}

Commented [BDS4]: I would not make such speculation, Basically the same holds true for the bace inhibitor trials and for the Aducanumab trial 


\begin{tabular}{|c|c|c|}
\hline & $\begin{array}{l}\text { modulator to alter the ratio } \\
\text { of } A \beta \text { peptides in favour of } \\
\text { shorter, less aggregatory } \\
\text { forms. }\end{array}$ & $\begin{array}{l}\text { 800mg bid tarenflurbil for } 18 \text { months. No } \\
\text { significant effects on primary outcome measures } \\
\text { of ADAS-cog and ADCS-activities of daily living } \\
\text { (Green et al. 2009). }\end{array}$ \\
\hline Semagecestat & $\begin{array}{l}\text { Small molecule non } \\
\text { competitive } \gamma \text {-secretase } \\
\text { inhibitor to prevent } \\
\text { production of all } A \beta \text { species. }\end{array}$ & $\begin{array}{l}2600 \text { mild-to-moderate AD patients randomized } \\
\text { to placebo, 100, 140mg semagecestat od for } 76 \\
\text { weeks in two trials (ClinicalTrials.gov identifiers } \\
\text { NCT00594568; NTC00762411) enrolled. Trials } \\
\text { were halted after interim analysis showed } \\
\text { increased incidence of skin cancer and worsening } \\
\text { of cognition and activities of daily living (Doody et } \\
\text { al. 2013). }\end{array}$ \\
\hline Bapineuzumab & $\begin{array}{l}\text { Humanized monoclonal } \\
\text { antibody directed at amino } \\
\text { acids 1-5 of Aß peptide. } \\
\text { Mediate amyloid plaque } \\
\text { clearance via binding to } \\
\text { plaque and promoting } \\
\text { microglial activation. }\end{array}$ & $\begin{array}{l}4500 \text { mild-to-moderate AD patients randomized } \\
\text { to placebo and } 0.5 \mathrm{mg} / \mathrm{kg} \text { IV every } 13 \text { weeks for } 18 \\
\text { months in ApoE4 carriers, and randomized to } \\
\text { placebo and } 0.5 \text { and } 1.0 \mathrm{mg} / \mathrm{kg} \text { IV every } 13 \text { weeks } \\
\text { for } 18 \text { months in ApoE4 non-carriers in four trials } \\
\text { (Clinical Trials.gov identfiers INCT00575055; } \\
\text { NCT00574132; NCT00676143; NCT00667810.) } \\
\text { Trials were halted after completion of two trials } \\
\text { demonstrated a failure to meet primary outcome } \\
\text { measures of cognition and activities of daily living } \\
\text { (Salloway et al. 2014). }\end{array}$ \\
\hline Solanezumab & $\begin{array}{l}\text { Humanized monoclonal } \\
\text { antibody directed at amino } \\
\text { acids } 16-24 \text { of } A ß \text {. Mediate } \\
\text { amyloid plaque clearance } \\
\text { via reduction of free } \\
\text { concentration of } A \beta \text { peptide } \\
\text { in the periphery and in CSF. }\end{array}$ & $\begin{array}{l}2000 \text { mild-to-moderate AD patients randomized } \\
\text { to placebo and } 400 \text { mg solanezumab monthly IV } \\
\text { for } 18 \text { months (Clinical Trials.gov identfiers } \\
\text { NCT00905372; NCT00904683). Trials failed to } \\
\text { meet their primary outcome measures of ADAS- } \\
\text { cog an ADCS-activities of daily living (Doody et al. } \\
\text { 2014). A secondary analysis of mild AD patients } \\
\text { pooled from both trials showed a significant } \\
\text { effect on cognition (Siemers et al. 2015). An } \\
\text { extension study revealed that the positive effects } \\
\text { on cognition in the mild AD group were sustained } \\
\text { over the next two years providing evidence for a } \\
\text { disease modifying effect (Liu-Seifert et al. 2015). }\end{array}$ \\
\hline $\begin{array}{l}\text { Gammagard }^{\circledast} \\
\text { Intravenous } \\
\text { Immunoglobulin }\end{array}$ & $\begin{array}{l}\text { Mixture of human } \\
\text { immunoglobulins that were } \\
\text { believed to reduce } \\
\text { peripheral } A \beta \text { levels. }\end{array}$ & $\begin{array}{l}\text { Trial data currently unpublished. } 390 \text { mild- } \\
\text { moderate } A D \text { patients randomized to } 0.2 \mathrm{~g} / \mathrm{kg} / 2 \\
\text { weeks and } 0.4 \mathrm{~g} / \mathrm{kg} / 2 \text { weeks versus placebo for } 18 \\
\text { months (ClinicalTrials.gov Identifier: } \\
\text { NCT00818662). Gammagard failed to reach its co- }\end{array}$ \\
\hline
\end{tabular}


Table 2. Amyloidocentric approaches in Phase $2 / 3$ clinical efficacy testing for symptomatic AD

\begin{tabular}{|c|c|c|c|}
\hline Name & Proposed mechanism of action. & Company & Trial characteristics \\
\hline $\begin{array}{l}\text { AZD3293 } \\
\text { LY3314814. }\end{array}$ & $\begin{array}{l}\text { Small molecule BACE inhibitor } \\
\text { to prevent production of all } A \beta \\
\text { species. }\end{array}$ & $\begin{array}{l}\text { AstraZeneca } \\
\text { Lilly }\end{array}$ & $\begin{array}{l}\text { ClinicalTrials.gov Identifier: NCT02245737 } \\
\text { Primary outcome measure: change from baseline in the Clinical } \\
\text { Dementia Rating - Sum of Boxes (CDR-SB) Score in early AD (mild } \\
\text { cognitive impaiment to mild AD) in a } 2 \text { year study. A } 3 / \text { amyloid relevant } \\
\text { inclusion critiera include positive amyloid PET scan or a lumbar } \\
\text { puncture to assay for abnormally low A } \beta \text { CSF. }\end{array}$ \\
\hline $\begin{array}{l}\text { Aducanumab } \\
\text { BlIB037. }\end{array}$ & $\begin{array}{l}\text { Human monoclonal antibody } \\
\text { that binds specifically to } \\
\text { amyloid plaque to facilitate } \\
\text { clearance. }\end{array}$ & Biogen & $\begin{array}{l}\text { ClinicalTrials.gov Identifier: NCT02477800/ NCT02484547 } \\
\text { Primary outcome measure: change from baseline in the CDR-SB Score } \\
\text { in early AD (mild cognitive impaiment to mild AD) in a } 1.5 \text { year study. } \\
A B / \text { amyloid relevant inclusion critiera include positive amyloid PET } \\
\text { scan. }\end{array}$ \\
\hline $\begin{array}{l}\text { Azeliragon } \\
\text { PF-04494700, } \\
\text { TTP488 }\end{array}$ & $\begin{array}{l}\text { Small molecule antagonist of } \\
\text { the receptor for advanced } \\
\text { glycation endproducts (RAGE) } \\
\text { with multiple } A \beta \text {-related } \\
\text { mechanims of action. }\end{array}$ & $\begin{array}{l}\text { Pfizer, TransTech } \\
\text { Pharma, Inc., vTV } \\
\text { Therapeutics LLC }\end{array}$ & $\begin{array}{l}\text { ClinicalTrials.gov Identifier: NCT02080364 } \\
\text { Co-primary outcome measures: change from baseline in Alzheimer's } \\
\text { Disease Assessment Scale - Cognitive (ADAS-cog); change from } \\
\text { baseline in CDR-SB in mild AD a } 1.5 \text { year study. }\end{array}$ \\
\hline Gantenerumab & $\begin{array}{l}\text { Human monoclonal antibody } \\
\text { that binds to conformational } \\
\text { epitopes on fibrillar } A \beta \text { to } \\
\text { facilitate clearance. }\end{array}$ & $\begin{array}{l}\text { Chugai } \\
\text { Pharmaceutical } \\
\text { Co., Ltd., } \\
\text { Hoffmann-La } \\
\text { Roche }\end{array}$ & $\begin{array}{l}\text { ClinicalTrials.gov Identifier: NCT0205160. } \\
\text { Co-primary outcome measures: change from baseline in ADAS-cog; } \\
\text { change from baseline in Alzheimer's Disease Cooperative Study- } \\
\text { Activities of Daily Living (ADCS-ADL) scores in mild AD in a } 2 \text { year study. } \\
\text { A } \beta \text { /amyloid relevant inclusion critiera include lumbar puncture to } \\
\text { assay for abnormally low A } \beta \text { CSF. }\end{array}$ \\
\hline $\begin{array}{l}\text { Solanezumab } \\
\text { LY2062430 }\end{array}$ & $\begin{array}{l}\text { Humanized monoclonal } \\
\text { antibody directed at amino } \\
\text { acids } 16-24 \text { of } A \beta \text {. Binds }\end{array}$ & Eli Lilly \& Co. & $\begin{array}{l}\text { ClinicalTrials.gov Identifier: NCT01900665 } \\
\text { Co-primary outcome measures: change from baseline in ADAS- } \\
\text { cog;change from baseline in ADCS-iADL scores in mild AD in a } 1.5 \text { year }\end{array}$ \\
\hline
\end{tabular}




\begin{tabular}{|l|l|l|l|}
\hline & $\begin{array}{l}\text { monomeric species to deplete } \\
\text { free } \mathrm{A} \beta \text { and reduce amyloid } \\
\text { plaque. }\end{array}$ & & $\begin{array}{l}\text { study. AB/amyloid relevant inclusion critiera include positive amyloid } \\
\text { PET scan or a lumbar puncture for to assay for abnormally low AB CSF. }\end{array}$ \\
\hline $\begin{array}{l}\text { Verubecestat } \\
\text { MK-8931 }\end{array}$ & $\begin{array}{l}\text { Small molecule BACE inhibitor } \\
\text { to prevent production of all A } \\
\text { species. }\end{array}$ & Merck & $\begin{array}{l}\text { ClinicalTrials.gov Identifier: NCT01739348. } \\
\text { Co-primary outcome measures: change from baseline in ADAS-cog; } \\
\text { change from baseline in ADCS-ADL scores in mild to moderate AD in a } \\
1.5 \text { year study. }\end{array}$ \\
\hline
\end{tabular}

Figure Legends

Figure 1. Amyloid precursor protein familial Alzheimer's disease mutations.

The diagram shows the $\beta$-site amyloid precursor protein cleaving enzyme 1 (BACE1) and $\psi$-secretase cleavage points and the protective and pathogenic amino acid changes mediated by APP mutations.

Figure 2. Modified Amyloid Cascade Hypothesis.

The scheme shows that the aggregation of $A B$ is a key event but it runs in parallel with tau dysfunction. At some point, amyloid plaque provokes increased tau pathology that spreads throughout the brain. This process is accelerated by widespread deleterious effects to brain cells leading to system failure and dementia. 
Acosta-Baena, N., Sepulveda-Falla, D., Lopera-Gomez, C. M., Jaramillo-Elorza, M. C., Moreno, S., AguirreAcevedo, D. C., Saldarriaga, A. and Lopera, F. (2011) Pre-dementia clinical stages in presenilin 1 E280A familial early-onset Alzheimer's disease: a retrospective cohort study. Lancet neurology, 10, 213-220.

Ahmed, M., Davis, J., Aucoin, D., Sato, T., Ahuja, S., Aimoto, S., Elliott, J. I., Van Nostrand, W. E. and Smith, S. O. (2010) Structural conversion of neurotoxic amyloid-beta(1-42) oligomers to fibrils. Nat. Struct. Mol. Biol., 17, 561-567.

Aisen, P. S., Gauthier, S., Ferris, S. H. et al. (2011) Tramiprosate in mild-to-moderate Alzheimer's disease - a randomized, double-blind, placebo-controlled, multi-centre study (the Alphase Study). Archives of medical science : AMS, 7, 102-111.

Alzheimer, A. (1907) Uber einen eigenartigc Erkrankung der Hirnrinde. Allgemeine Zeitschrift fur Psyciatrie und Psychisch-Gerichtliche Medizin, 64, 3.

Arendt, T., Holzer, M., Grossmann, A., Zedlick, D. and Bruckner, M. K. (1995) Increased expression and subcellular translocation of the mitogen activated protein kinase kinase and mitogen-activated protein kinase in Alzheimer's disease. Neuroscience, 68, 5-18.

Arriagada, P. V., Growdon, J. H., Hedley-Whyte, E. T. and Hyman, B. T. (1992) Neurofibrillary tangles but not senile plaques parallel duration and severity of Alzheimer's disease. Neurology, 42, 631-639.

Bales, K. R., Verina, T., Cummins, D. J. et al. (1999) Apolipoprotein E is essential for amyloid deposition in the APP(V717F) transgenic mouse model of Alzheimer's disease. Proceedings of the National Academy of Sciences of the United States of America, 96, 15233-15238.

Bedse, G., Di Domenico, F., Serviddio, G. and Cassano, T. (2015) Aberrant insulin signaling in Alzheimer's disease: current knowledge. Front Neurosci, 9, 204.

Benilova, I., Gallardo, R., Ungureanu, A. A. et al. (2014) The Alzheimer disease protective mutation A2T modulates kinetic and thermodynamic properties of amyloid-beta (Abeta) aggregation. J Biol Chem, 289, 30977-30989.

Benilova, I., Karran, E. and De Strooper, B. (2012) The toxic Abeta oligomer and Alzheimer's disease: an emperor in need of clothes. Nature neuroscience, 15, 349-357.

Bentahir, M., Nyabi, O., Verhamme, J., Tolia, A., Horre, K., Wiltfang, J., Esselmann, H. and De Strooper, B. (2006) Presenilin clinical mutations can affect gamma-secretase activity by different mechanisms. Journal of neurochemistry, 96, 732-742.

Beyreuther, K. and Masters, C. L. (1991) Amyloid precursor protein (APP) and beta A4 amyloid in the etiology of Alzheimer's disease: precursor-product relationships in the derangement of neuronal function. Brain Pathol, 1, 241-251.

Borchelt, D. R., Thinakaran, G., Eckman, C. B. et al. (1996) Familial Alzheimer's disease-linked presenilin 1 variants elevate Abeta1-42/1-40 ratio in vitro and in vivo. Neuron, 17, 1005-1013.

Braak, H., Thal, D. R., Ghebremedhin, E. and Del Tredici, K. (2011) Stages of the pathologic process in Alzheimer disease: age categories from 1 to 100 years. Journal of neuropathology and experimental neurology, 70, 960-969.

Buee, L., Hof, P. R., Bouras, C., Delacourte, A., Perl, D. P., Morrison, J. H. and Fillit, H. M. (1994) Pathological alterations of the cerebral microvasculature in Alzheimer's disease and related dementing disorders. Acta neuropathologica, 87, 469-480.

Cannon, J. P., O'Driscoll, M. and Litman, G. W. (2012) Specific lipid recognition is a general feature of CD300 and TREM molecules. Immunogenetics, 64, 39-47. 
Cardoso, S. M., Santana, I., Swerdlow, R. H. and Oliveira, C. R. (2004) Mitochondria dysfunction of Alzheimer's disease cybrids enhances Abeta toxicity. J Neurochem, 89, 1417-1426.

Chavez-Gutierrez, L., Bammens, L., Benilova, I. et al. (2012) The mechanism of gamma-Secretase dysfunction in familial Alzheimer disease. The EMBO journal, 31, 2261-2274.

Chow, H. M. and Herrup, K. (2015) Genomic integrity and the ageing brain. Nat Rev Neurosci, 16, 672684.

Citron, M., Oltersdorf, T., Haass, C., McConlogue, L., Hung, A. Y., Seubert, P., Vigo-Pelfrey, C., Lieberburg, I. and Selkoe, D. J. (1992) Mutation of the beta-amyloid precursor protein in familial Alzheimer's disease increases beta-protein production. Nature, 360, 672-674.

Corder, E. H., Saunders, A. M., Strittmatter, W. J., Schmechel, D. E., Gaskell, P. C., Small, G. W., Roses, A. D., Haines, J. L. and Pericak-Vance, M. A. (1993) Gene dosage of apolipoprotein E type 4 allele and the risk of Alzheimer's Disease in late onset families. Science, 261, 921-923.

Craft, S., Baker, L. D., Montine, T. J. et al. (2012) Intranasal insulin therapy for Alzheimer disease and amnestic mild cognitive impairment: a pilot clinical trial. Arch Neurol, 69, 29-38.

Cullen, K. M., Kocsi, Z. and Stone, J. (2006) Microvascular pathology in the aging human brain: evidence that senile plaques are sites of microhaemorrhages. Neurobiology of aging, 27, 1786-1796.

Cummings, J. L., Morstorf, T. and Zhong, K. (2014) Alzheimer's disease drug-development pipeline: few candidates, frequent failures. Alzheimer's research \& therapy, 6, 37-37.

Daws, M. R., Sullam, P. M., Niemi, E. C., Chen, T. T., Tchao, N. K. and Seaman, W. E. (2003) Pattern recognition by TREM-2: binding of anionic ligands. Journal of immunology, 171, 594-599.

de la Torre, J. C. (2004) Is Alzheimer's disease a neurodegenerative or a vascular disorder? Data, dogma, and dialectics. Lancet neurology, 3, 184-190.

de la Torre, J. C. and Mussivand, T. (1993) Can disturbed brain microcirculation cause Alzheimer's disease? Neurological research, 15, 146-153.

De Strooper, B., Iwatsubo, T. and Wolfe, M. S. (2012) Presenilins and gamma-secretase: structure, function, and role in Alzheimer Disease. Cold Spring Harbor perspectives in medicine, 2, a006304.

De Strooper, B. and Karran, E. (2016) The Cellular Phase of Alzheimer's Disease. Cell, 164, 603-615.

De Strooper, B., Saftig, P., Craessaerts, K., Vanderstichele, H., Guhde, G., Annaert, W., Von Figura, K. and Van Leuven, F. (1998) Deficiency of presenilin-1 inhibits the normal cleavage of amyloid precursor protein. Nature, 391, 387-390.

Delacourte, A., David, J. P., Sergeant, N. et al. (1999) The biochemical pathway of neurofibrillary degeneration in aging and Alzheimer's disease. Neurology, 52, 1158-1165.

Di Fede, G., Catania, M., Morbin, M. et al. (2009) A recessive mutation in the APP gene with dominantnegative effect on amyloidogenesis. Science, 323, 1473-1477.

Doody, R. S., Raman, R., Farlow, M. et al. (2013) A phase 3 trial of semagacestat for treatment of Alzheimer's disease. N Engl J Med, 369, 341-350.

Doody, R. S., Thomas, R. G., Farlow, M. et al. (2014) Phase 3 trials of solanezumab for mild-to-moderate Alzheimer's disease. N Engl J Med, 370, 311-321.

Dovey, H. F., John, V., Anderson, J. P. et al. (2001) Functional gamma-secretase inhibitors reduce betaamyloid peptide levels in brain. Journal of neurochemistry, 76, 173-181.

Duering, M., Grimm, M. O., Grimm, H. S., Schroder, J. and Hartmann, T. (2005) Mean age of onset in familial Alzheimer's disease is determined by amyloid beta 42. Neurobiology of aging, 26, 785788.

Duff, K., Eckman, C., Zehr, C. et al. (1996) Increased amyloid-beta42(43) in brains of mice expressing mutant presenilin 1. Nature, 383, 710-713.

Esler, W. P., Kimberly, W. T., Ostaszewski, B. L. et al. (2000) Transition-state analogue inhibitors of gamma-secretase bind directly to presenilin-1. Nature cell biology, 2, 428-434. 
Ferreira, S. T. and Klein, W. L. (2011) The Abeta oligomer hypothesis for synapse failure and memory loss in Alzheimer's disease. Neurobiol. Learn. Mem., 96, 529-543.

Fischer, O. (1907) Miliare Nekrosen mit drusigen Wucherungen der Neurofibrillen, eine regelma" ssige Vera“ nderung der Hirnrinde bei seniler Demenz. Monatsschr Psychiat Neurol, 22, 17.

Fischer, V. W., Siddiqi, A. and Yusufaly, Y. (1990) Altered angioarchitecture in selected areas of brains with Alzheimer's disease. Acta neuropathologica, 79, 672-679.

Frontzek, K., Lutz, M. I., Aguzzi, A., Kovacs, G. G. and Budka, H. (2016) Amyloid-beta pathology and cerebral amyloid angiopathy are frequent in iatrogenic Creutzfeldt-Jakob disease after dural grafting. Swiss medical weekly, 146, w14287.

Glenner, G. G. and Wong, C. W. (1984a) Alzheimer's disease and Down's syndrome: sharing of a unique cerebrovascular amyloid fibril protein. Biochemical and biophysical research communications, 122, 1131-1135.

Glenner, G. G. and Wong, C. W. (1984b) Alzheimer's disease: initial report of the purification and characterization of a novel cerebrovascular amyloid protein. Biochemical and biophysical research communications, 120, 885-890.

Goate, A., Chartier-Harlin, M. C., Mullan, M. et al. (1991) Segregation of a missense mutation in the amyloid precursor protein gene with familial Alzheimer's disease [see comments]. Nature, 349, 704-706.

Godbolt, A. K., Cipolotti, L., Watt, H., Fox, N. C., Janssen, J. C. and Rossor, M. N. (2004) The natural history of Alzheimer disease: a longitudinal presymptomatic and symptomatic study of a familial cohort. Archives of neurology, 61, 1743-1748.

Gomez-Isla, T., Price, J. L., McKeel, D. W., Jr., Morris, J. C., Growdon, J. H. and Hyman, B. T. (1996) Profound loss of layer II entorhinal cortex neurons occurs in very mild Alzheimer's disease. The Journal of neuroscience : the official journal of the Society for Neuroscience, 16, 4491-4500.

Green, R. C., Schneider, L. S., Amato, D. A., Beelen, A. P., Wilcock, G., Swabb, E. A., Zavitz, K. H. and Tarenflurbil Phase 3 Study, G. (2009) Effect of tarenflurbil on cognitive decline and activities of daily living in patients with mild Alzheimer disease: a randomized controlled trial. JAMA : the journal of the American Medical Association, 302, 2557-2564.

Guerreiro, R., Wojtas, A., Bras, J. et al. (2013) TREM2 variants in Alzheimer's disease. The New England journal of medicine, 368, 117-127.

Haass, C., Schlossmacher, M. G., Hung, A. Y. et al. (1992) Amyloid beta-peptide is produced by cultured cells during normal metabolism [see comments]. Nature, 359, 322-325.

Haass, C. and Selkoe, D. J. (2007) Soluble protein oligomers in neurodegeneration: lessons from the Alzheimer's amyloid beta-peptide. Nat. Rev. Mol. Cell Biol., 8, 101-112.

Hardy, J. and Allsop, D. (1991) Amyloid deposition as the central event in the aetiology of Alzheimer's disease. Trends Pharmacol Sci, 12, 383-388.

Hardy, J. A. and Higgins, G. A. (1992) Alzheimer's disease: the amyloid cascade hypothesis. Science., 256, 184-185.

Hayden, E. Y. and Teplow, D. B. (2013) Amyloid beta-protein oligomers and Alzheimer's disease. Alzheimer's research \& therapy, 5, 60.

Hefti, F., Goure, W. F., Jerecic, J., Iverson, K. S., Walicke, P. A. and Krafft, G. A. (2013) The case for soluble Abeta oligomers as a drug target in Alzheimer's disease. Trends Pharmacol. Sci., 34, 261-266.

Hepler, R. W., Grimm, K. M., Nahas, D. D. et al. (2006) Solution state characterization of amyloid betaderived diffusible ligands. Biochemistry, 45, 15157-15167.

Herrup, K. (2015) The case for rejecting the amyloid cascade hypothesis. Nat Neurosci, 18, 794-799.

Holmes, C., Boche, D., Wilkinson, D. et al. (2008) Long-term effects of Abeta42 immunisation in Alzheimer's disease: follow-up of a randomised, placebo-controlled phase I trial. Lancet, $\mathbf{3 7 2 ,}$ 216-223. 
Holmes, C. and Lovestone, S. (2002) The clinical phenotype of familial and sporadic late onset Alzheimer's disease. International journal of geriatric psychiatry, 17, 146-149.

Holtzman, D. M., Bales, K. R., Tenkova, T. et al. (2000) Apolipoprotein E isoform-dependent amyloid deposition and neuritic degeneration in a mouse model of Alzheimer's disease. Proceedings of the National Academy of Sciences of the United States of America, 97, 2892-2897.

Holtzman, D. M., Bales, K. R., Wu, S., Bhat, P., Parsadanian, M., Fagan, A. M., Chang, L. K., Sun, Y. and Paul, S. M. (1999) Expression of human apolipoprotein E reduces amyloid-beta deposition in a mouse model of Alzheimer's disease. J. Clin. Invest., 103, R15-R21.

Holtzman, D. M., Herz, J. and Bu, G. (2012) Apolipoprotein E and Apolipoprotein E Receptors: Normal Biology and Roles in Alzheimer Disease. Cold Spring Harbor perspectives in medicine, 2, a006312.

Hong, S., Ostaszewski, B. L., Yang, T., O'Malley, T. T., Jin, M., Yanagisawa, K., Li, S., Bartels, T. and Selkoe, D. J. (2014) Soluble Abeta oligomers are rapidly sequestered from brain ISF in vivo and bind GM1 ganglioside on cellular membranes. Neuron, 82, 308-319.

Hori, Y., Hashimoto, T., Wakutani, Y. et al. (2007) The Tottori (D7N) and English (H6R) familial Alzheimer disease mutations accelerate Abeta fibril formation without increasing protofibril formation. $J$ Biol Chem, 282, 4916-4923.

Hoyer, S. (1991) Abnormalities of glucose metabolism in Alzheimer's disease. Ann N Y Acad Sci, 640, 5358.

Hoyer, S., Oesterreich, K. and Wagner, O. (1988) Glucose metabolism as the site of the primary abnormality in early-onset dementia of Alzheimer type? J Neurol, 235, 143-148.

Hussain, I., Powell, D., Howlett, D. R. et al. (1999) Identification of a Novel Aspartic Protease (Asp 2) as beta-Secretase. Mol. Cell. Neurosci., 14, 419-427.

Iliff, J. J., Wang, M., Liao, Y. et al. (2012) A Paravascular Pathway Facilitates CSF Flow Through the Brain Parenchyma and the Clearance of Interstitial Solutes, Including Amyloid $\beta$. Science translational medicine, 4, 147ra111-147ra111.

Inayathullah, M. and Teplow, D. B. (2011) Structural dynamics of the DeltaE22 (Osaka) familial Alzheimer's disease-linked amyloid beta-protein. Amyloid, 18, 98-107.

Irizarry, M. C., McNamara, M., Fedorchak, K., Hsiao, K. and Hyman, B. T. (1997a) APPSw transgenic mice develop age-related $\mathrm{A}$ beta deposits and neuropil abnormalities, but no neuronal loss in CA1. Journal of neuropathology and experimental neurology, 56, 965-973.

Irizarry, M. C., Soriano, F., McNamara, M., Page, K. J., Schenk, D., Games, D. and Hyman, B. T. (1997b) Abeta deposition is associated with neuropil changes, but not with overt neuronal loss in the human amyloid precursor protein V717F (PDAPP) transgenic mouse. The Journal of neuroscience : the official journal of the Society for Neuroscience, 17, 7053-7059.

Jack, C. R., Jr., Vemuri, P., Wiste, H. J. et al. (2011) Evidence for ordering of Alzheimer disease biomarkers. Archives of neurology, 68, 1526-1535.

Jack, C. R., Jr., Vemuri, P., Wiste, H. J. et al. (2012) Shapes of the Trajectories of 5 Major Biomarkers of Alzheimer Disease. Archives of neurology.

Jack, C. R., Jr., Wiste, H. J., Weigand, S. D. et al. (2015) Age, Sex, and APOE epsilon4 Effects on Memory, Brain Structure, and beta-Amyloid Across the Adult Life Span. JAMA neurology, 72, 511-519.

Jarrett, J. T., Berger, E. P. and Lansbury, P. T., Jr. (1993) The carboxy terminus of the beta amyloid protein is critical for the seeding of amyloid formation: implications for the pathogenesis of Alzheimer's disease. Biochemistry, 32, 4693-4697.

Jaunmuktane, Z., Mead, S., Ellis, M. et al. (2015) Evidence for human transmission of amyloid-beta pathology and cerebral amyloid angiopathy. Nature, 525, 247-250.

Jonsson, T., Atwal, J. K., Steinberg, S. et al. (2012) A mutation in APP protects against Alzheimer's disease and age-related cognitive decline. Nature, 488, 96-99. 
Jonsson, T., Stefansson, H., Steinberg, S. et al. (2013) Variant of TREM2 associated with the risk of Alzheimer's disease. The New England journal of medicine, 368, 107-116.

Kang, J., Lemaire, H. G., Unterbeck, A., Salbaum, J. M., Masters, C. L., Grzeschik, K. H., Multhaup, G., Beyreuther, K. and Muller-Hill, B. (1987) The precursor of Alzheimer's disease amyloid A4 protein resembles a cell-surface receptor. Nature, 325, 733-736.

Karran, E. and Hardy, J. (2014) A critique of the drug discovery and phase 3 clinical programs targeting the amyloid hypothesis for Alzheimer disease. Ann Neurol, 76, 185-205.

Karran, E., Mercken, M. and De Strooper, B. (2011) The amyloid cascade hypothesis for Alzheimer's disease: an appraisal for the development of therapeutics. Nature reviews. Drug discovery, 10, 698-712.

Kayed, R., Head, E., Sarsoza, F. et al. (2007) Fibril specific, conformation dependent antibodies recognize a generic epitope common to amyloid fibrils and fibrillar oligomers that is absent in prefibrillar oligomers. Mol Neurodegener, 2, 18.

Khan, S. M., Cassarino, D. S., Abramova, N. N. et al. (2000) Alzheimer's disease cybrids replicate betaamyloid abnormalities through cell death pathways. Annals of neurology, 48, 148-155.

King, M. P. and Attardi, G. (1989) Human cells lacking mtDNA: repopulation with exogenous mitochondria by complementation. Science, 246, 500-503.

Kleinberger, G., Yamanishi, Y., Suarez-Calvet, M. et al. (2014) TREM2 mutations implicated in neurodegeneration impair cell surface transport and phagocytosis. Science translational medicine, 6, 243ra286.

Koffie, R. M., Hyman, B. T. and Spires-Jones, T. L. (2011) Alzheimer's disease: synapses gone cold. Molecular neurodegeneration, 6, 63.

Kumar-Singh, S., Pirici, D., McGowan, E., Serneels, S., Ceuterick, C., Hardy, J., Duff, K., Dickson, D. and Van Broeckhoven, C. (2005) Dense-core plaques in Tg2576 and PSAPP mouse models of Alzheimer's disease are centered on vessel walls. The American journal of pathology, 167, 527543.

Kumar-Singh, S., Theuns, J., Van Broeck, B. et al. (2006) Mean age-of-onset of familial alzheimer disease caused by presenilin mutations correlates with both increased Abeta42 and decreased Abeta 40. Human mutation, 27, 686-695.

Labbadia, J. and Morimoto, R. I. (2015) The biology of proteostasis in aging and disease. Annu Rev Biochem, 84, 435-464.

Lambert, J. C., Ibrahim-Verbaas, C. A., Harold, D. et al. (2013) Meta-analysis of 74,046 individuals identifies 11 new susceptibility loci for Alzheimer's disease. Nature genetics, 45, 1452-1458.

Lannert, H. and Hoyer, S. (1998) Intracerebroventricular administration of streptozotocin causes longterm diminutions in learning and memory abilities and in cerebral energy metabolism in adult rats. Behav Neurosci, 112, 1199-1208.

Lanz, T. A., Karmilowicz, M. J., Wood, K. M. et al. (2006) Concentration-dependent modulation of amyloid-beta in vivo and in vitro using the gamma-secretase inhibitor, LY-450139. The Journal of pharmacology and experimental therapeutics, 319, 924-933.

Lee, H. G., Casadesus, G., Nunomura, A. et al. (2009) The neuronal expression of MYC causes a neurodegenerative phenotype in a novel transgenic mouse. Am J Pathol, 174, 891-897.

Li, Y. M., Xu, M., Lai, M. T. et al. (2000) Photoactivated gamma-secretase inhibitors directed to the active site covalently label presenilin 1 . Nature, 405, 689-694.

Lin, M. T. and Beal, M. F. (2006) Mitochondrial dysfunction and oxidative stress in neurodegenerative diseases. Nature, 443, 787-795.

Lin, X., Koelsch, G., Wu, S., Downs, D., Dashti, A. and Tang, J. (2000) Human aspartic protease memapsin 2 cleaves the beta-secretase site of beta-amyloid precursor protein. Proceedings of the National Academy of Sciences of the United States of America, 97, 1456-1460. 
Lippa, C. F., Saunders, A. M., Smith, T. W. et al. (1996) Familial and sporadic Alzheimer's disease: neuropathology cannot exclude a final common pathway. Neurology, 46, 406-412.

Liu-Seifert, H., Aisen, P. S., Andersen, S. W., Holdridge, K. C. and Siemers, E. R. (2015) Delayed-start analyses of up to 3.5 years in the phase 3 solanezumab Expedition program in mild Alzheimer's disease

\section{Alzheimers \& Dementia, 11, 2}

Liu, C.-C., Kanekiyo, T., Xu, H. and Bu, G. (2013) Apolipoprotein E and Alzheimer disease: risk, mechanisms and therapy. Nat Rev Neurol, 9, 106-118.

Liu, P., Reed, M. N., Kotilinek, L. A. et al. (2015) Quaternary Structure Defines a Large Class of Amyloidbeta Oligomers Neutralized by Sequestration. Cell Rep, 11, 1760-1771.

Lodato, M. A., Woodworth, M. B., Lee, S. et al. (2015) Somatic mutation in single human neurons tracks developmental and transcriptional history. Science, 350, 94-98.

Maloney, J. A., Bainbridge, T., Gustafson, A. et al. (2014) Molecular mechanisms of Alzheimer disease protection by the A673T allele of amyloid precursor protein. The Journal of biological chemistry, 289, 30990-31000.

Marchesi, V. T. (2011) Alzheimer's dementia begins as a disease of small blood vessels, damaged by oxidative-induced inflammation and dysregulated amyloid metabolism: implications for early detection and therapy. FASEB J., 25, 5-13.

Masters, C. L., Simms, G., Weinman, N. A., Multhaup, G., McDonald, B. L. and Beyreuther, K. (1985) Amyloid plaque core protein in Alzheimer disease and Down syndrome. Proceedings of the National Academy of Sciences of the United States of America, 82, 4245-4249.

McClean, P. L. and Holscher, C. (2014) Liraglutide can reverse memory impairment, synaptic loss and reduce plaque load in aged APP/PS1 mice, a model of Alzheimer's disease. Neuropharmacology, 76 Pt A, 57-67.

McGeer, P. L., Itagaki, S. and McGeer, E. G. (1988) Expression of the histocompatibility glycoprotein HLADR in neurological disease. Acta neuropathologica, 76, 550-557.

McKinnon, P. J. (2013) Maintaining genome stability in the nervous system. Nat Neurosci, 16, $1523-$ 1529.

McShea, A., Lee, H. G., Petersen, R. B., Casadesus, G., Vincent, I., Linford, N. J., Funk, J. O., Shapiro, R. A. and Smith, M. A. (2007) Neuronal cell cycle re-entry mediates Alzheimer disease-type changes. Biochim Biophys Acta, 1772, 467-472.

Morgen, K. and Frolich, L. (2015) The metabolism hypothesis of Alzheimer's disease: from the concept of central insulin resistance and associated consequences to insulin therapy. J Neural Transm (Vienna), 122, 499-504.

Mucke, L. and Selkoe, D. J. (2012) Neurotoxicity of amyloid beta-protein: synaptic and network dysfunction. Cold Spring Harbor perspectives in medicine, 2, a006338.

Naslund, J., Haroutunian, V., Mohs, R., Davis, K. L., Davies, P., Greengard, P. and Buxbaum, J. D. (2000) Correlation between elevated levels of amyloid beta-peptide in the brain and cognitive decline. JAMA : the journal of the American Medical Association, 283, 1571-1577.

Nelson, P. T., Head, E., Schmitt, F. A. et al. (2011) Alzheimer's disease is not "brain aging": neuropathological, genetic, and epidemiological human studies. Acta Neuropathol, 121, 571587.

Ni, C. L., Shi, H. P., Yu, H. M., Chang, Y. C. and Chen, Y. R. (2011) Folding stability of amyloid-beta 40 monomer is an important determinant of the nucleation kinetics in fibrillization. FASEB J., 25, 1390-1401. 
Nickerson, D. A., Taylor, S. L., Fullerton, S. M., Weiss, K. M., Clark, A. G., Stengard, J. H., Salomaa, V., Boerwinkle, E. and Sing, C. F. (2000) Sequence diversity and large-scale typing of SNPs in the human apolipoprotein E gene. Genome research, 10, 1532-1545.

Nicoll, J. A., Wilkinson, D., Holmes, C., Steart, P., Markham, H. and Weller, R. O. (2003) Neuropathology of human Alzheimer disease after immunization with amyloid-beta peptide: a case report. Nature medicine, 9, 448-452.

Nochlin, D., van Belle, G., Bird, T. D. and Sumi, S. M. (1993) Comparison of the severity of neuropathologic changes in familial and sporadic Alzheimer's disease. Alzheimer disease and associated disorders, 7, 212-222.

Ono, K., Condron, M. M. and Teplow, D. B. (2009) Structure-neurotoxicity relationships of amyloid betaprotein oligomers. Proceedings of the National Academy of Sciences of the United States of America, 106, 14745-14750.

Paquet, C., Amin, J., Mouton-Liger, F. et al. (2015) Effect of active Abeta immunotherapy on neurons in human Alzheimer's disease. J. Pathol., 235, 721-730.

Pastor, P., Roe, C. M., Villegas, A. et al. (2003) Apolipoprotein Eepsilon4 modifies Alzheimer's disease onset in an E280A PS1 kindred. Annals of neurology, 54, 163-169.

Poduri, A., Evrony, G. D., Cai, X. and Walsh, C. A. (2013) Somatic mutation, genomic variation, and neurological disease. Science, 341, 1237758.

Polvikoski, T., Sulkava, R., Myllykangas, L. et al. (2001) Prevalence of Alzheimer's disease in very elderly people: a prospective neuropathological study. Neurology, 56, 1690-1696.

Potter, R., Patterson, B. W., Elbert, D. L. et al. (2013) Increased in vivo amyloid-beta42 production, exchange, and loss in presenilin mutation carriers. Science translational medicine, 5, 189ra177.

Price, J. L. and Morris, J. C. (1999) Tangles and plaques in nondemented aging and "preclinical" Alzheimer's disease. Annals of neurology, 45, 358-368.

Prince, M., Albanese, E., Guerchet, M. and Prina, M. (2014) World Alzheimer Report 2014: Dementia and risk reduction: An analysis of protective and modifiable risk factors. Alzheimer's Disease International.

Reiman, E. M., Langbaum, J. B., Tariot, P. N. et al. (2016) CAP-advancing the evaluation of preclinical Alzheimer disease treatments. Nat Rev Neurol, 12, 56-61.

Rubenstein, E. (1998) Relationship of senescence of cerebrospinal fluid circulatory system to dementias of the aged. The Lancet, 351, 283-285.

Salloway, S., Sperling, R., Fox, N. C. et al. (2014) Two phase 3 trials of bapineuzumab in mild-to-moderate Alzheimer's disease. N Engl J Med, 370, 322-333.

Scheuner, D., Eckman, C., Jensen, M. et al. (1996) Secreted amyloid beta-protein similar to that in the senile plaques of Alzheimer's disease is increased in vivo by the presenilin 1 and 2 and APP mutations linked to familial Alzheimer's disease [see comments]. Nature medicine, 2, 864-870.

Schmechel, D. E., Saunders, A. M., Strittmatter, W. J., Crain, B. J., Hulette, C. M., Joo, S. H., PericakVance, M. A., Goldgaber, D. and Roses, A. D. (1993) Increased amyloid beta-peptide deposition in cerebral cortex as a consequence of apolipoprotein $E$ genotype in late-onset Alzheimer disease. Proceedings of the National Academy of Sciences of the United States of America, 90, 9649-9653.

Selkoe, D. J. (1991) The molecular pathology of Alzheimer's disease. Neuron, 6, 487-498.

Seubert, P., Vigo-Pelfrey, C., Esch, F. et al. (1992) Isolation and quantification of soluble Alzheimer's beta-peptide from biological fluids [see comments]. Nature, 359, 325-327.

Shearman, M. S., Beher, D., Clarke, E. E. et al. (2000) L-685,458, an aspartyl protease transition state mimic, is a potent inhibitor of amyloid beta-protein precursor gamma-secretase activity. Biochemistry, 39, 8698-8704. 
Shoji, M., Golde, T. E., Ghiso, J. et al. (1992) Production of the Alzheimer amyloid beta protein by normal proteolytic processing. Science, 258, 126-129.

Siemers, E. R., Sundell, K. L., Carlson, C. et al. (2015) Phase 3 solanezumab trials: Secondary outcomes in mild Alzheimer's disease patients. Alzheimers Dement.

Sinha, S., Anderson, J. P., Barbour, R. et al. (1999) Purification and cloning of amyloid precursor protein beta-secretase from human brain [In Process Citation]. Nature, 402, 537-540.

Small, S. A. and Duff, K. (2008) Linking Abeta and tau in late-onset Alzheimer's disease: a dual pathway hypothesis. Neuron, 60, 534-542.

Snider, B. J., Norton, J., Coats, M. A. et al. (2005) Novel presenilin 1 mutation (S170F) causing Alzheimer disease with Lewy bodies in the third decade of life. Archives of neurology, 62, 1821-1830.

Sonnen, J. A., Breitner, J. C., Lovell, M. A., Markesbery, W. R., Quinn, J. F. and Montine, T. J. (2008) Free radical-mediated damage to brain in Alzheimer's disease and its transgenic mouse models. Free Radic Biol Med, 45, 219-230.

Sperling, R. A., Aisen, P. S., Beckett, L. A. et al. (2011) Toward defining the preclinical stages of Alzheimer's disease: recommendations from the National Institute on Aging-Alzheimer's Association workgroups on diagnostic guidelines for Alzheimer's disease. Alzheimers Dement, 7, 280-292.

Steen, E., Terry, B. M., Rivera, E. J., Cannon, J. L., Neely, T. R., Tavares, R., Xu, X. J., Wands, J. R. and de la Monte, S. M. (2005) Impaired insulin and insulin-like growth factor expression and signaling mechanisms in Alzheimer's disease--is this type 3 diabetes? J Alzheimers Dis, 7, 63-80.

Suzuki, N., Cheung, T. T., Cai, X. D., Odaka, A., Otvos, L., Jr., Eckman, C., Golde, T. E. and Younkin, S. G. (1994) An increased percentage of long amyloid beta protein secreted by familial amyloid beta protein precursor (beta APP717) mutants. Science, 264, 1336-1340.

Swerdlow, R. H., Burns, J. M. and Khan, S. M. (2014) The Alzheimer's disease mitochondrial cascade hypothesis: progress and perspectives. Biochim Biophys Acta, 1842, 1219-1231.

Swerdlow, R. H. and Kahn, S. M. (2004) A 'mitochondrial cascade hypothesis' for sporadic Alzheimer's disease. Med. Hypotheses, 63, 12.

Szaruga, M., Veugelen, S., Benurwar, M. et al. (2015) Qualitative changes in human gamma-secretase underlie familial Alzheimer's disease. J. Exp. Med., 212, 2003-2013.

Tarasoff-Conway, J. M., Carare, R. O., Osorio, R. S. et al. (2015) Clearance systems in the brainimplications for Alzheimer disease. Nat Rev Neurol, 11, 457-470.

Tomiyama, T., Nagata, T., Shimada, H. et al. (2008) A new amyloid beta variant favoring oligomerization in Alzheimer's-type dementia. Annals of neurology, 63, 377-387.

Upadhaya, A. R., Lungrin, I., Yamaguchi, H., Fandrich, M. and Thal, D. R. (2012) High-molecular weight Abeta oligomers and protofibrils are the predominant Abeta species in the native soluble protein fraction of the AD brain. J Cell Mol Med, 16, 287-295.

Van Broeckhoven, C. and Kumar-Singh, S. (2006) Genetics and pathology of alpha-secretase site AbetaPP mutations in the understanding of Alzheimer's disease. Journal of Alzheimer's disease : JAD, 9 , 389-398.

Vassar, R., Bennett, B. D., Babu-Khan, S. et al. (1999) Beta-secretase cleavage of Alzheimer's amyloid precursor protein by the transmembrane aspartic protease BACE [see comments]. Science, 286, 735-741.

Verghese, P. B., Castellano, J. M. and Holtzman, D. M. (2011) Apolipoprotein E in Alzheimer's disease and other neurological disorders. Lancet Neurol, 10, 241-252.

Vincent, I., Rosado, M. and Davies, P. (1996) Mitotic mechanisms in Alzheimer's disease? J Cell Biol, 132, 413-425.

Viola, K. L. and Klein, W. L. (2015) Amyloid beta oligomers in Alzheimer's disease pathogenesis, treatment, and diagnosis. Acta neuropathologica, 129, 183-206. 
Walker, L. C. and Jucker, M. (2015) Neurodegenerative diseases: expanding the prion concept. Annu Rev Neurosci, 38, 87-103.

Walsh, D. M. and Selkoe, D. J. (2007) A beta oligomers - a decade of discovery. Journal of neurochemistry, 101, 1172-1184.

Ward, R. V., Jennings, K. H., Jepras, R. et al. (2000) Fractionation and characterization of oligomeric, protofibrillar and fibrillar forms of beta-amyloid peptide. The Biochemical journal, 348 Pt 1, 137144.

Weggen, S., Eriksen, J. L., Das, P. et al. (2001) A subset of NSAIDs lower amyloidogenic Abeta42 independently of cyclooxygenase activity. Nature, 414, 212-216.

Weiner, M. W., Aisen, P. S., Jack, C. R., Jr. et al. (2010) The Alzheimer's disease neuroimaging initiative: progress report and future plans. Alzheimer's \& dementia : the journal of the Alzheimer's Association, 6, 202-211 e207.

Weiner, M. W., Veitch, D. P., Aisen, P. S. et al. (2015) Impact of the Alzheimer's Disease Neuroimaging Initiative, 2004 to 2014. Alzheimer's \& dementia : the journal of the Alzheimer's Association, 11, 865-884.

Welander, H., Franberg, J., Graff, C., Sundstrom, E., Winblad, B. and Tjernberg, L. O. (2009) Abeta43 is more frequent than Abeta40 in amyloid plaque cores from Alzheimer disease brains. Journal of neurochemistry, 110, 697-706.

Weller, R. O., Subash, M., Preston, S. D., Mazanti, I. and Carare, R. O. (2008) Perivascular drainage of amyloid-beta peptides from the brain and its failure in cerebral amyloid angiopathy and Alzheimer's disease. Brain pathology, 18, 253-266.

Wolfe, M. S., Xia, W., Moore, C. L., Leatherwood, D. D., Ostaszewski, B., Rahmati, T., Donkor, I. O. and Selkoe, D. J. (1999a) Peptidomimetic probes and molecular modeling suggest that Alzheimer's gamma-secretase is an intramembrane-cleaving aspartyl protease. Biochemistry, 38, 4720-4727.

Wolfe, M. S., Xia, W., Ostaszewski, B. L., Diehl, T. S., Kimberly, W. T. and Selkoe, D. J. (1999b) Two transmembrane aspartates in presenilin-1 required for presenilin endoproteolysis and gammasecretase activity. Nature, 398, 513-517.

Yan, R., Bienkowski, M. J., Shuck, M. E. et al. (1999) Membrane-anchored aspartyl protease with Alzheimer's disease beta-secretase activity [see comments]. Nature, 402, 533-537.

Yang, T., O'Malley, T. T., Kanmert, D., Jerecic, J., Zieske, L. R., Zetterberg, H., Hyman, B. T., Walsh, D. M. and Selkoe, D. J. (2015) A highly sensitive novel immunoassay specifically detects low levels of soluble Abeta oligomers in human cerebrospinal fluid. Alzheimers Res Ther, 7, 14.

Ye, L., Fritschi, S. K., Schelle, J. et al. (2015) Persistence of Abeta seeds in APP null mouse brain. Nat Neurosci, 18, 1559-1561.

Zhang-Nunes, S. X., Maat-Schieman, M. L., van Duinen, S. G., Roos, R. A., Frosch, M. P. and Greenberg, S. M. (2006) The cerebral beta-amyloid angiopathies: hereditary and sporadic. Brain pathology, 16, 30-39.

Zhang, B., Gaiteri, C., Bodea, L. G. et al. (2013) Integrated systems approach identifies genetic nodes and networks in late-onset Alzheimer's disease. Cell, 153, 707-720. 